\title{
Human herpesvirus 6 and chronic fatigue syndrome
}

\author{
Daniel Eymard, MD, François lebel, MD, Mark Miller, MD, François Turgeon, RT
}

\begin{abstract}
D Eymard, F Lebel, M Mmler, F Turgeon. Human herpesvirus 6 and chronic fatigue syndrome. Can J Infect Dis 1993;4(4):199-202. The cause of chronic fatigue syndrome (CFS) is still enigmatic. Using indirect immunofluorescence testing for measuring antibody against human herpesvirus 6 (HHV-6), this study investigated the association of CFS with infection by HHV-6. Seventeen patients (group A) fulfilling the Centers for Disease Control (CDC) definition for CFS were compared with eight patients (group B) with chronic fatigue but not meeting the $\mathrm{CDC}$ criteria. No significant difference was found between the two groups for 30 parameters including sex, age, exposure to children and serology for Epstein-Barr virus, cytomegalovirus, herpes simplex virus, and toxoplasma. Univariate analysis showed that patients in group A complained more frequently of a sore throat, headache and of recurrent type of fatigue. These three parameters are discriminant in identifying patients who will meet the CDC case definition of CFS. The titre of antibody against HHV-6 in group A (1:99) was significantly higher than in group B (1:15) ( $\mathrm{P}=0.007)$. Elevated HHV-6 titres suggests that this virus could be a cofactor in the pathogenesis of CFS.
\end{abstract}

Key Words: Chronic fatigue syndrome, Human herpesvirus 6

\section{Herpèsvirus 6 humain et syndrome de fatigue chronique}

RÉSUMÉ: La cause du syndrome de fatigue chronique (SFC) demeure énigmatique. À l'aide d'épreuves par immunofluorescence indirecte pour la mesure des anticorps dirigés contre l'Herpèsvirus 6 humain (HHV-6), nous avons étudié les liens possibles entre le SFC et le HHV-6. Dix-sept patients (groupe A) correspondant à la définition de SFC du Laboratoire de lutte contre la maladie (CDC) ont été comparés à huit patients (groupe B) atteints de fatigue chronique non conforme à la définition du CDC. Il n'y avait aucune différence significative entre les deux groupes à l'égard de 30 paramètres, y compris l'âge, l'exposition à des enfants, et la présence sérologique du virus Epstein-Barr, du cytomégalovirus, du virus Herpès simplex et de toxoplasma. L'analyse univariée à révélé que les patients du groupe A se plaignaient plus souvent de maux de gorge, de céphalées, et d'un type de fatigue récurrente. Ces trois paramètres ont servi à identifier les patients qui répondent aux critères de la définition de SFC du CDC. Le titre de l'anticorps dirigé contre HHV-6 dans le groupe A (1:99) s'est révélé nettement plus élevé que dans le groupe B (1:15) $(\mathrm{P}=0,007)$. Les titres de HHV-6 élevés donnent à penser que ce virus pourrait être un cofacteur dans la pathogenèse du SFC.

Department of Microbiology and Division of Infectious Diseases, Montreal General Hospital, McGill University, Montreal, Quebec Correspondence and reprints: Dr Daniel Eymard, Centre Hospitalier Pierre Boucher, 1333 Boulevard Jacques Cartier Est, Longueuil, Quebec J4M 2A5. Telephone (514) 468-8111, Fax (514) 468-8240

This study was presented in part to the 31st Interscience Conference on Antimicrobial Agents and Chemotherapy in Chicago, Illinois, September 1991

Received for publication July 13, 1992. Accepted November 20, 1992 
$I^{N}$ N THE PAST DECADE, MULTIPLE STUDIES HAVE REPORTED patients who were severely disabled by chronic fatigue and other somatic complaints, referring to these findings as chronic fatigue syndrome (CFS). No strict criteria have been used to enrol patients in studies which have investigated potential causes of this syndrome, which remain unknown. Association with different infectious agents has been suggested, including: Epstein-Barr virus (EBV) (1-3), enterovirus (4) and more recently, human herpesvirus 6 (HHV-6) $(5,6)$. Using the Centers for Disease Control (CDC) criteria for defining CFS (7), we retrospectively studied a group of individuals complaining of chronic fatigue and investigated the association of CFS with infection by HHV-6.

\section{PATIENTS AND METHODS}

The charts of 25 patients diagnosed as having CFS by two infectious diseases clinicians at one institution between December 1986 and April 1989 were reviewed. Patients were divided into two groups: group A included 17 patients fulfilling the CDC criteria for CFS and group B consisted of eight patients not meeting these criteria.

All patients had a complete medical history using an open-ended interview, including explicit questioning about the nature and timing of the fatigue and the presence of minor criteria for CFS. Fatigue was classified as recurrent or persistent, with recurrent fatigue qualitatively defined as fatigue alternating with periods of energy and activity ranging from improved to near normal level, while persistent fatigue was defined as being present daily.

Physical examination was performed with specific attention to the physical criteria for CFS. With few exceptions, laboratory evaluation included: complete blood counts; blood smear; biochemical profile; heterophile antibody; creatine phosphokinase; sedimentation rate; antinuclear antibody; thyroid-stimulating hormone; urinalysis; chest radiograph; tuberculin skin test (5 TU); serology for human immunodifficiency virus (LAV-EIA, Genetic System Corp, Seattle, Washington), cytomegalovirus (CMV) and herpes simplex virus (HSV) (complement fixation), toxoplasma (hemagglutination inhibition), EBV (immunofluorescence) and HHV-6. For CMV, HSV and toxoplasma, antibody titres of less than 1 in 4 were considered negative.

Performance of HHV-6 serological testing was conducted on sera that had been frozen at $-20^{\circ} \mathrm{C}$. HSB-2, a $\mathrm{T}$ lymphoblastoid cell line, was established in suspension culture with RPMI 1640 medium (Flow Laboratories Inc), $10 \%$ fetal calf serum (heat inactivated) and antibiotics. These cells were infected with the Dv strain of HHV-6 (courtesy of Dr NA Brown, Cornell University Medical College, Manhasset, New York) and were used for preparing slides on day 8 of infection, using methanol $99 \%$ at $-20^{\circ} \mathrm{C}$ for 15 mins for fixation. Uninfected cells were used as a negative control slide for each serum. The sera were inactivated at $56^{\circ} \mathrm{C}$ for 30 mins and serial
TABLE 1

Demographic data of study participants

\begin{tabular}{|c|c|c|}
\hline Demographic & Group A* & Group B ${ }^{\dagger}$ \\
\hline Number & 17 & 8 \\
\hline Female:male & $11: 6$ & $3: 5$ \\
\hline Mean age (years) & 34.9 & 41.1 \\
\hline \multicolumn{3}{|l|}{ Marital status } \\
\hline Single & 7 & 1 \\
\hline Married & 8 & 5 \\
\hline Divorced & 2 & 1 \\
\hline Children (mean) & 1.2 & 2.0 \\
\hline Exposure to children (work) & 2 & 1 \\
\hline \multicolumn{3}{|l|}{ Highest education } \\
\hline University & 11 & 2 \\
\hline College & 5 & 3 \\
\hline High school & 1 & 2 \\
\hline \multicolumn{3}{|l|}{ Annual salary } \\
\hline$<\$ 10,000$ & 2 & 1 \\
\hline$\$ 10,000$ to $\$ 25,000$ & 9 & 4 \\
\hline$>\$ 25,000$ & 6 & 2 \\
\hline Travel overseas & 6 & 1 \\
\hline Smoker & 3 & 4 \\
\hline History of mononucleosis & 3 & 2 \\
\hline Psychiatric history & 1 & 2 \\
\hline Anxiolytic medication & 3 & 4 \\
\hline Mean number of physicians consulted & 4.3 & 3.4 \\
\hline
\end{tabular}

twofold dilutions were made from an initial concentration of 1:10. Twenty-five microlitres of each dilution was overlaid on the slide and incubated at $37^{\circ} \mathrm{C}$ for $30 \mathrm{mins}$. After two washings with phosphate buffered saline, the slide was overlaid with $20 \mu \mathrm{L}$ of a 1:40 dilution of fluorescein isothiocyanate-labelled goat antihuman IgG with $5 \mu \mathrm{L} / \mathrm{mL}$ of Evan's blue and incubated at $37^{\circ} \mathrm{C}$ for 30 mins. The slides were washed twice more with phosphate buffered saline, air-dried and mounted with glycerol. Readings were done on a fluorescent Zeiss microscope at 400x magnification with a 450 to $490 \mathrm{~mm}$ filter.

Microscopic evaluation of fluorescence for each serum was performed by two trained observers who did not know the source of the specimen. For any serum producing readings of more than one dilution difference between the observers, a third observer evaluated the slides and the two closest readings of the three were averaged for the final result. Any cytoplasmic or nuclear apple green fluorescence was considered indicative of the presence of antibody.

\section{STATISTICAL ANALYSIS}

The $\chi^{2}$ and Fisher exact tests were used when comparing discrete variables, and the Mann-Whitney U test for continuous variables. Serology results were compared by conversion to the $\log _{2}$ of the reciprocal titre (8). A P value of 0.05 or less was interpreted as indicating a significant association. 
TABLE 2

\section{Symptoms and signs of study participants}

\begin{tabular}{|c|c|c|}
\hline & Group A* & Group B $^{\dagger}$ \\
\hline \multicolumn{3}{|l|}{ Symptoms } \\
\hline \multicolumn{3}{|l|}{ Fatigue type } \\
\hline Recurrent & 13 & 1 \\
\hline Persistent & 4 & 7 \\
\hline Sore throat & 17 & 3 \\
\hline Sudden onset of disease & 14 & 5 \\
\hline Fever and/or chills & 14 & 4 \\
\hline Tender lymph nodes & 12 & 2 \\
\hline Muscle weakness & 15 & 7 \\
\hline Myalgia & 12 & 3 \\
\hline Arthralgia & 11 & 1 \\
\hline Post exercise fatigue & 17 & 7 \\
\hline Headache & 13 & 1 \\
\hline Neuropsychological symptoms & 16 & 6 \\
\hline Sleep disturbance & 15 & 7 \\
\hline \multicolumn{3}{|l|}{ Signs } \\
\hline Fever & 1 & 0 \\
\hline Pharyngitis & 8 & 1 \\
\hline Palpable adenopathy & 8 & 2 \\
\hline
\end{tabular}

-Group A Chronic fatigue syndrome patients; ${ }^{\dagger}$ Group B Fatigue (nonchronic fatigue syndrome) patients

\section{RESULTS}

In univariate analysis, no statistical difference in age or sex distribution was found between groups A and B. No significant difference in the two groups was found with respect to marital status, number of children, exposure to children at work, education level, salary, travel outside Canada in the year prior to illness, smoking habits, prior history of infectious mononucleosis or psychiatric evaluation, anxiolytic therapy or number of professionals consulted for fatigue (Table 1).

All patients in groups A and B fulfilled the two major $\mathrm{CDC}$ criteria for $\mathrm{CFS}$. The mean number of $\mathrm{CDC}$ minor criteria present was 10.2 in group A patients and 6.1 in group B patients. Patients in group A complained more frequently of recurrent rather than persistent fatigue $(\mathrm{P}=0.007)$. Among the 11 symptoms and three signs of the CDC definition of CFS, sore throat and headache were present more often in individuals in group $\mathrm{A}$ $(\mathrm{P}=0.002$ and $\mathrm{P}=0.007$, respectively) (Table 2$)$.

No consistent hematological, biochemical or immunological anomalies were demonstrated in our baseline evaluation. All individuals were HIV antibody negative. Serological results for EBV, CMV, HSV and toxoplasma were available for 17,14 , nine and 16 patients, respectively, in group A; and for seven, seven, four and seven patients in group B. As shown in Table 3, there were no significant differences between groups A and B in the reciprocal geometric mean titre (GMT) of antibody against CMV, HSV and toxoplasma (Mann-Whitney U test). Antibody against the different EBV related antigens were separated according to categories of antibody in-
TABLE 3

Serological results of study participants

\begin{tabular}{lcc}
\hline Test & Group A $^{*}$ & Group B $^{\dagger}$ \\
\hline CMV (reciprocal GMT) & 4.4 & 2.6 \\
HSV (reciprocal GMT) & 4.3 & 2.0 \\
Toxoplasma (reciprocal GMT) & 2.7 & 2.0 \\
EBV-VCA (number of persons) & & \\
$<1 / 10$ & 0 & 0 \\
$\geq 1 / 10 ;<1 / 100$ & 3 & 2 \\
$\geq 1 / 100 ;<1 / 1000$ & 12 & 5 \\
$\geq 1 / 1000$ & 2 & 0 \\
EBNA (number of persons) & & \\
$<1 / 10$ & 0 & 0 \\
$\geq 1 / 10 ;<1 / 100$ & 6 & 4 \\
$\geq 1 / 100 ;<1 / 1000$ & 10 & 3 \\
$\geq 1 / 1000$ & 1 & 0 \\
EB-EA (number of persons) & & \\
$<1 / 10$ & 4 & 1 \\
$\geq 1 / 10 ;<1 / 80$ & 8 & 2 \\
$\geq 1 / 80$ & 5 & 15 \\
HHV-6 (reciprocal GMT) & & \\
\hline
\end{tabular}

"Group A Chronic fatigue syndrome patients; ${ }^{\dagger}$ Group B Fatigue (nonchronic fatigue syndrome) patients; ${ }^{7} H H V-6$ serology available for all patients in each group; CMV Cytomegalovirus; GMT Geometric mean titre; HSV Herpes simplex virus; EBV-VCA Epstein-Barr viral capsid antigen; EBNA Epstein-Barr nuclear antigen; EB-EA Epstein-Barr early antigen; HHV6 Human herpesvirus 6

terval; no difference was found between the two groups with respect to the distribution of patients. For the HHV-6 immunofluorescence reading, there was a 95\% correlation within one dilution between observers. The reciprocal anti-HHV-6 GMT of group A was significantly higher than that of group $\mathrm{B}$ (99 versus $15 ; \mathrm{P}=0.007$ ).

\section{DISCUSSION}

The demographic data of our patients are similar to previous reports, with a predominance of women in their mid-thirties (9). When evaluating these patients complaining of chronic fatigue, the two major criteria of the $\mathrm{CDC}$ case definition of CFS seem well founded. Unfortunately, the minor criteria are numerous and nonspecific. Three symptoms were more discriminant in identifying those patients that meet the $\mathrm{CDC}$ case definition: the presence of a recurrent type of fatigue, headache and a sore throat. Another cohort of patients fulfilling the CDC criteria for CFS found that sore throat was the most frequent symptom, with a $96 \%$ prevalence (10).

HHV- 6 is known to be highly prevalent in the USA (11), Japan (12) and the Quebec City area (13). Primary infection is known to occur in the first years of life and is responsible for the development of exanthema subitum (14). Reactivation of HHV-6 has been associated with clinical disease in bone marrow transplant patients (15). Reactivation of latent HHV- 6 would seem an attractive hypothesis to explain the morbidity of CFS. Ablashi et al (5) have reported elevated antibody titres to HHV-6 in eight 
patients with chronic fatigue, and one study reported evidence of active replication of HHV-6 in peripheral mononuclear cells of $70 \%$ of patients (79 of 113) with chronic fatigue compared with $20 \%$ of control subjects (eight of 40$)\left(\mathrm{P}<10^{-8}\right)(16)$. However, in those two studies it is unclear if the patients satisfied the CDC definition of CFS. In a group of 63 patients meeting the CDC case definition for CFS, Landay et al (17) found a GMT to HHV-6 of 201 which was significantly higher than the GMT of 104 in their control group. Our results are similar and suggest that when evaluating patients with chronic fatigue, an elevated antibody titre against HHV6 is an objective criterion to help identify those who will meet the CDC definition of CFS.

A recent report (18) of seven patients meeting the CDC criteria for CFS showed that six of the patients had IgG reciprocal titres to HHV-6 ranging from 320 to 640 . At our Institution, nine of 17 patients with CFS (group A) had reciprocal titres to HHV-6 equal to or above 80 while they were equal to or below 40 in all of the eight patients in group B. Larger serological studies should be performed to identify a significant threshold of antibody discriminative for CFS.

Polyclonal B-cell stimulation during acute EBV and CMV

ACKNOWLEDGEMENTS: The authors thank Dr David Portnoy for patient referrals and Mme Glen Brook for manuscript preparation.

\section{REFERENCES}

1. Tobi M, Morag A, Ravid Z, et al. Prolonged atypical illness associated with serologic evidence of persistent Epstein-Barr virus infection. Lancet 1982;i:61-4.

2. Straus SE, Tosato G, Armstrong G, et al. Persisting illness and fatigue in adults with evidence of Epstein-Barr virus infection. Ann Intern Med 1985; 102:7-16.

3. Jones JF, Ray G, Minnich LL, Hicks MJ, Kibler R, Lucas DO. Evidence for active Epstein-Barr virus infection in patients with persistent unexplained illness: Elevated antiearly antigen antibodies. Ann Intern Med 1985;102:1-7.

4. Yousef GE, Bell EJ, Mann GF, et al. Chronic enterovirus infection in patients with postviral fatigue syndrome. Lancet 1988;i:146-50.

5. Ablashi DV, Josephs SF, Buchbinder A, et al. Human B-lymphotropic virus (human herpesvirus-6). J Virol Methods 1988;21:29-48.

6. Dale JK, Straus SE, Salahuddin ZS, et al. The InoueMelnick virus, human herpesvirus type 6 and the chronic fatigue syndrome. Ann Intern Med 1989;110:92-3. (Lett)

7. Holmes GP, Kaplan JE, Gantz NM, et al. Chronic fatigue syndrome: A working case defintion. Ann Intern Med 1988; 108:387-9.

8. White C. Statistical methods in serum survey. In: Paul JR, White C, eds. Serological epidemiology. New York: Academic Press, 1972:19-32.

9. Komaroff AL, Buchwald D. Symptoms and signs of chronic fatigue syndrome. Rev Infect Dis 1991;13(Suppl 1):8-11

10. Straus SE, Dale JK, Tobi M, et al. Acyclovir treatment of the chronic fatigue syndrome. N Engl J Med infection has been suggested to augment HHV-6 IgG titres (19). In our patients, EBV and CMV titres were not significantly different between group A and group B.

Gold et al (20) did not find any difference in the HHV-6 titres between their patients and controls. This may be explained by the fact that only six of their 26 patients fulfilled the CDC criteria: most of their patients were probably similar to group B of the present study. Further studies involving various groups of patients should be performed to document the HHV-6 antibody titre in different populations.

\section{CONCLUSIONS}

When evaluating patients with chronic fatigue, the presence of a recurrent rather than persistent fatigue, a sore throat, headache and elevated antibody titre against HHV-6 is more frequent in those who satisfy the CDC definition criteria of chronic fatigue syndrome. Further studies should be done to determine if the high HHV-6 titre could serve as an objective and discriminative criterion in the case definition of CFS. Elevated HHV-6 titres in patients with CFS suggests that reactivation of this virus could be a cofactor in the pathogenesis of this disease.

1988;319:1692-8.

11. Brown NA, Sumaya CV, Liu CR, et al. Fall in human herpesvirus 6 seropositivity with age. Lancet 1988;ii:396-7.

12. Okuno T, Takahashi $\mathrm{K}$, Balachandra $\mathrm{K}$, et al. Seroepidemiology of human herpesvirus 6 infection in normal children and adults. J Clin Microbiol 1989;27:651-3.

13. Deschênes L, Joly JR, Couillard M, Richer G. Seroprevalence of antibodies against human herpesvirus 6 in the Quebec City area. Can J Infect Dis 1992;3:179-84.

14. Yamanishi K, Okuno T, Shiraki K, et al. Identification of human herpersvirus- 6 as a causal agent for exanthem subitum. Lancet 1988;i:1065-7.

15. Asano Y, Yoshikawa T, Suga S, Nakashima T, Yazaki T. Reactivation of herpesvirus type 6 in children receiving bone marrow transplants for leukaemia. N Engl J Med 1991;324:634-5.

16. Buchwald D, Cheney PR, Peterson DL, et al. A chronic illness characterized by fatigue, neurologic and immunologic disorders, and active human herpesvirus type 6 infection. Ann Intern Med 1992;116:103-13.

17. Landay AL, Jessop C, Lennette ET, Levy JA. Chronic fatigue syndrome: Clinical condition associated with immune activation. Lancet 1991;338:707-12.

18. Joseph SF, Henry B, Balachandran N, et al. HHV-6 reactivation in chronic fatigue syndrome. Lancet 1991;337:1346-7.

19. Linde A, Fridell E, Dahl H, Andersson J, Biberfeld P, Wahren B. Effect of primary Epstein-Barr virus infection on human herpesvirus 6, cytomegalovirus and measles virus immunoglobulin $\mathrm{G}$ titres. J Clin Microbiol 1990;28:211-5.

20. Gold D, Bowden R, Sixbey J, et al. Chronic fatigue: A prospective clinical and virologic study. JAMA 1990;264:48-53. 


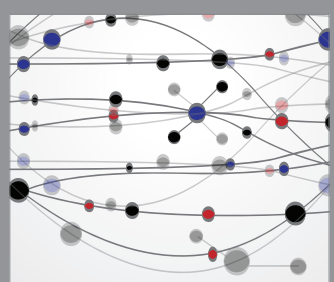

The Scientific World Journal
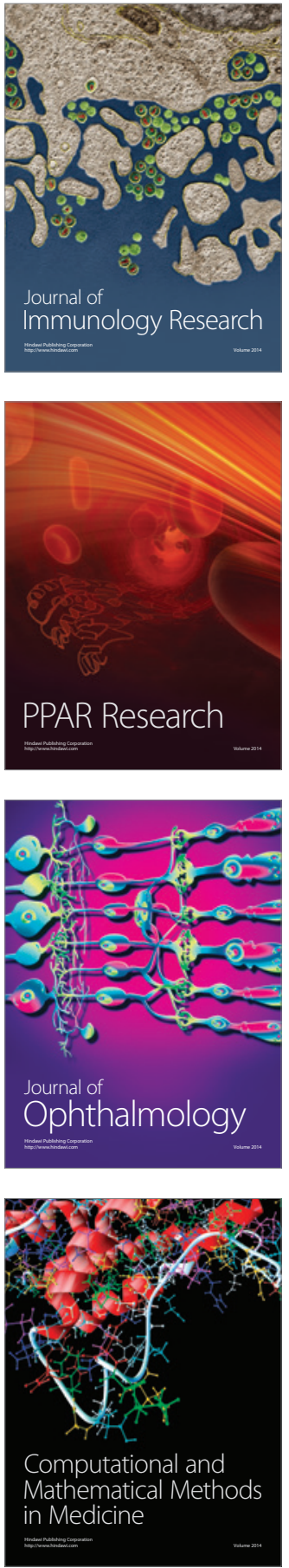

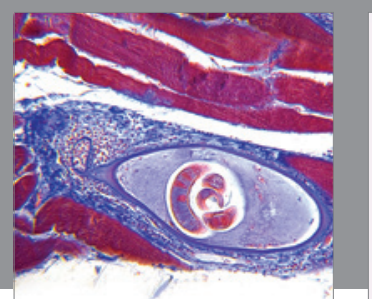

Gastroenterology Research and Practice

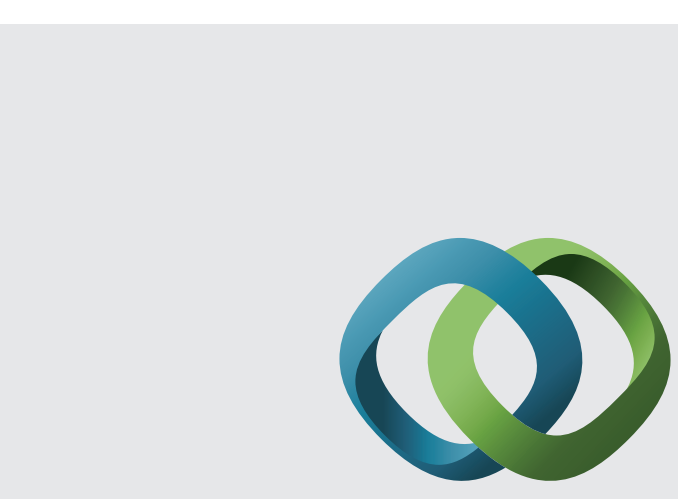

\section{Hindawi}

Submit your manuscripts at

http://www.hindawi.com
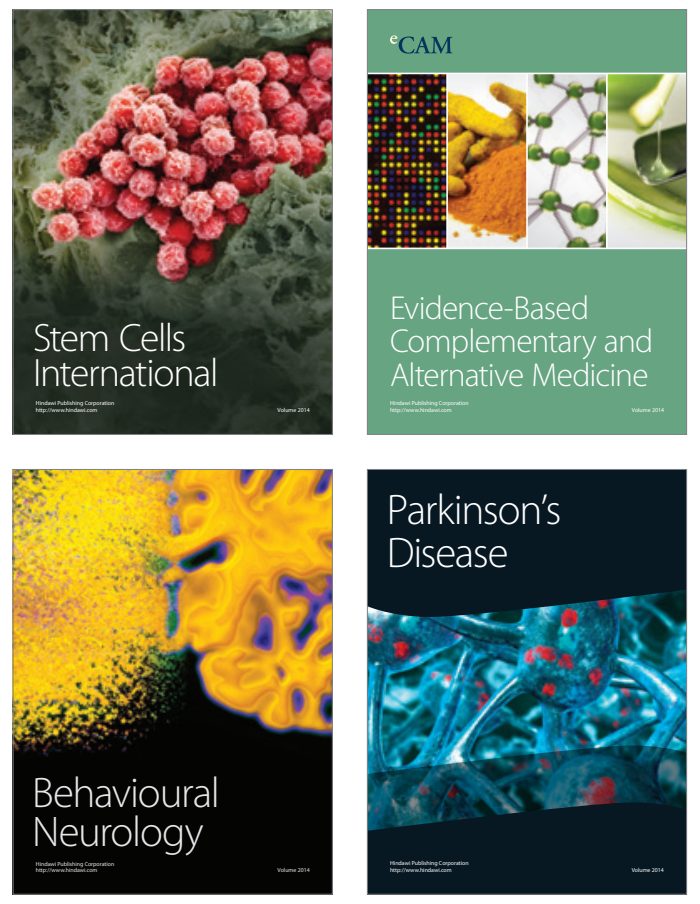
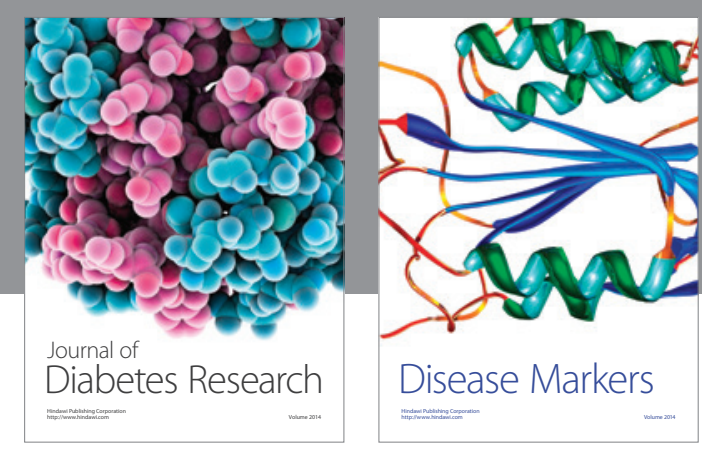

Disease Markers
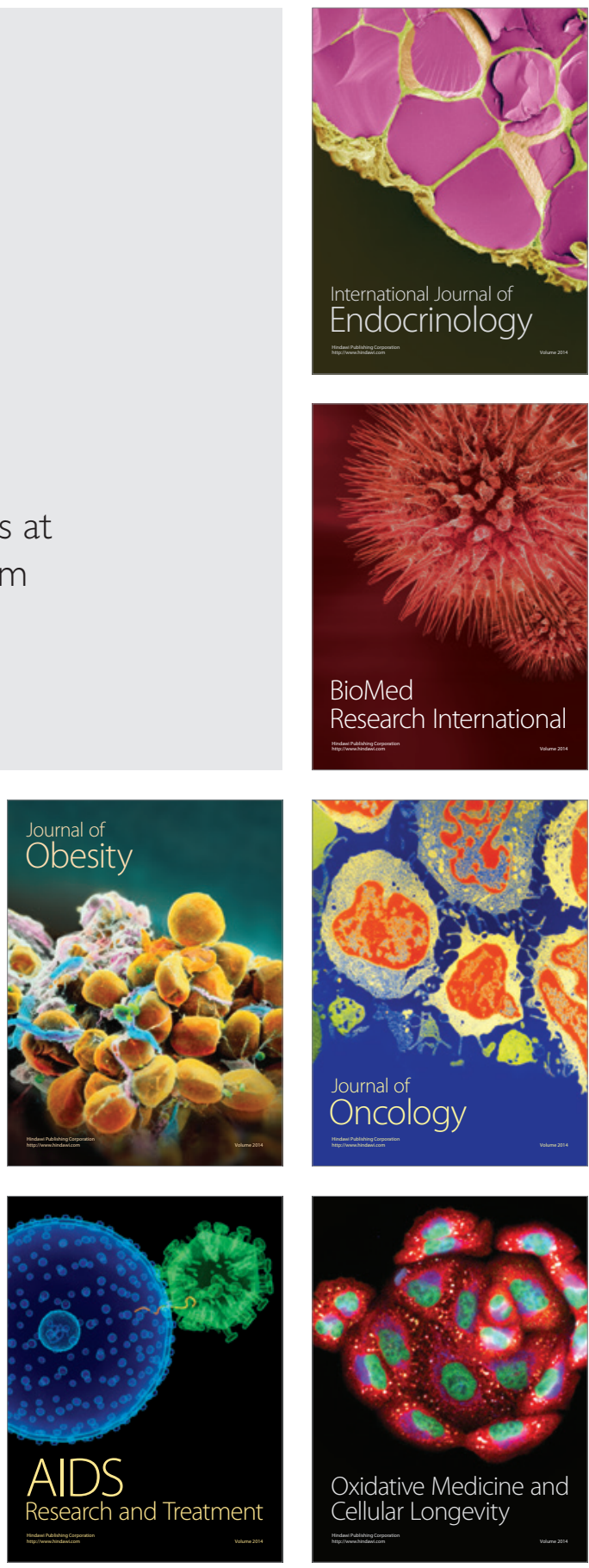